\title{
Criteria for topdressing nitrogen application to common bean using chlorophyll meter
}

\author{
Suelen Cristina Mendonça Maia(1), Rogério Peres Soratto(2), \\ Suzane Maria Liebe ${ }^{(2)}$ and Adriana Queiroz de Almeida ${ }^{(3)}$
}

\begin{abstract}
(1)Instituto Federal Goiano, Campus Avançado Cristalina, Rua Araguaia, s/no, Loteamento 71, Setor Oeste, CEP $73850-000$ Cristalina, GO, Brazil. E-mail: suelen.maia@ifgoiano.edu.br (2)Universidade Estadual Paulista, Faculdade de Ciências Agronômicas, Departamento de Produção e Melhoramento Vegetal, Campus de Botucatu, Fazenda Experimental Lageado, Caixa Postal 237, CEP 18610-307 Botucatu, SP, Brazil. E-mail: soratto@fca.unesp.br, suzane@liebe.com.br ${ }^{(3)}$ Instituto Federal Baiano, Campus Uruçuca, Rua Dr. João Nascimento, s/no, CEP 45680-000 Uruçuca, BA, Brazil. E-mail: adrianaq_almeida@yahoo.com.br
\end{abstract}

\begin{abstract}
The objective of this work was to establish the diagnostic leaf and the nitrogen sufficiency index (NSI) values most appropriate to estimate $\mathrm{N}$ requirement by the 'Pérola' common bean (Phaseolus vulgaris), based on chlorophyll meter monitoring. The diagnostic leaf was defined in an experiment with five $\mathrm{N}$ rates, and up to four sampling dates of the diagnostic leaves were evaluated (first, second, and third completely expanded leaves from the apex). The NSI was established in two crop seasons, under six N managements: $\mathrm{M} 1,40 \mathrm{~kg} \mathrm{ha}^{-1} \mathrm{~N}$ at sowing $+80 \mathrm{~kg} \mathrm{ha}^{-1} 10$ days after emergence (DAE) + $80 \mathrm{~kg} \mathrm{ha}^{-1} 20$ DAE (reference rate); M2, $20 \mathrm{~kg} \mathrm{ha}^{-1}$ at sowing $+40 \mathrm{~kg} \mathrm{ha}^{-1} 10 \mathrm{DAE}+40 \mathrm{~kg} \mathrm{ha}^{-1} 20$ DAE (recommended rate); M3, $20 \mathrm{~kg} \mathrm{ha}^{-1}$ at sowing $+30 \mathrm{~kg} \mathrm{ha}^{-1}$ when NSI $<96 \%$; M4, $20 \mathrm{~kg} \mathrm{ha}^{-1}$ at sowing $+30 \mathrm{~kg} \mathrm{ha}^{-1}$ when NSI $<93 \%$; M5, $20 \mathrm{~kg} \mathrm{ha}^{-1} \mathrm{~N}$ at sowing $+30 \mathrm{~kg} \mathrm{ha}^{-1}$ when $\mathrm{NSI}<90 \%$; and M6, without $\mathrm{N}$ application. The relative chlorophyll index readings on the second fully expanded leaf, at $21 \mathrm{DAE}$, and on the third leaf, at 28 and $35 \mathrm{DAE}$, are more precise to estimate the requirement of $\mathrm{N}$ by common bean. The NSI of $90 \%$ is more effective than the NSI of 93 or $96 \%$ for defining the moment for $\mathrm{N}$ topdressing application.
\end{abstract}

Index terms: Phaseolus vulgaris, diagnostic leaf, nitrogen fertilization, nitrogen sufficiency index, nitrogen use efficiency, relative chlorophyll index.

\section{Critérios para a aplicação do nitrogênio em cobertura no feijoeiro comum com uso de clorofilômetro}

\begin{abstract}
Resumo - O objetivo deste trabalho foi estabelecer a folha diagnose e os valores do índice de suficiência de nitrogênio (ISN) mais adequados para estimar a necessidade de $\mathrm{N}$ pela cultura do feijoeiro (Phaseolus vulgaris) comum 'Pérola', mediante monitoramento com clorofilômetro. A definição da folha diagnose foi feita em experimento com cinco doses de $\mathrm{N}$, e até quatro épocas de amostragem das folhas diagnóstico foram avaliadas (primeira, segunda e terceira folhas completamente expandidas a partir do ápice). O ISN foi estabelecido em duas safras, sob seis manejos de $\mathrm{N}$ : M1, $40 \mathrm{~kg} \mathrm{ha}^{-1}$ de N na semeadura $+80 \mathrm{~kg} \mathrm{ha}^{-1} 10$ dias após a emergência $(\mathrm{DAE})+80 \mathrm{~kg} \mathrm{ha}^{-1} 20 \mathrm{DAE}$ (referência); M2, $20 \mathrm{~kg} \mathrm{ha}^{-1}$ na semeadura $+40 \mathrm{~kg} \mathrm{ha}^{-1} 10 \mathrm{DAE}+40 \mathrm{~kg} \mathrm{ha}^{-1} 20 \mathrm{DAE}$ (dose recomendada); M3, $20 \mathrm{~kg} \mathrm{ha}^{-1}$ na semeadura $+30 \mathrm{~kg} \mathrm{ha}^{-1}$ quando ISN $<96 \%$; M4, $20 \mathrm{~kg} \mathrm{ha}^{-1}$ na semeadura + $30 \mathrm{~kg} \mathrm{ha}^{-1}$ quando ISN $<93 \%$; M5, $20 \mathrm{~kg} \mathrm{ha}^{-1}$ na semeadura + $30 \mathrm{~kg} \mathrm{ha}^{-1}$ quando ISN $<90 \%$; e M6, sem aplicação de N. As leituras do índice relativo de clorofila na segunda folha completamente expandida, aos 21 DAE, e na terceira folha, aos 28 e $35 \mathrm{DAE}$, são mais precisas para estimar a demanda de $\mathrm{N}$ pelo feijoeiro comum. O ISN de 90\% é mais eficiente que os de 93 ou 96\%, na definição do momento de aplicação do $\mathrm{N}$ em cobertura.
\end{abstract}

Termos para indexação: Phaseolus vulgaris, folha diagnose, adubação nitrogenada, índice de suficiência de nitrogênio, eficiência de uso do nitrogênio, índice relativo de clorofila.

\section{Introduction}

The proper management of nitrogen fertilization is one of the main determinants of high grain yield and profitability in the common bean (Phaseolus vulgaris L.) crop (Rapassi et al., 2003; Silveira et al., 2003; Soratto et al., 2014). Given the high N concentration in the grains and other tissues of the plant, $\mathrm{N}$ is the nutrient most absorbed and removed by the bean plant (Perez et al., 2013; Soratto et al., 2013b).

In Brazil, the efficiency of use of $\mathrm{N}$ fertilizers in the production of annual crops such as common bean is 
approximately $50 \%$; the causes of this low value are related to inadequate rates and times of application, as well as leaching losses, denitrification, immobilization, and soil erosion (Santos \& Fageria, 2007; Soratto et al., 2014). Excess of N, especially in the vegetative phase, may cause an excessive increase in the leaf area, which may result in self-shading, consequently decreasing the photosynthetic efficiency and transpiration of plants (Santos \& Fageria, 2007). Thus, to maximize grain uptake and grain yield, the $\mathrm{N}$ fertilization strategy should aim to improve the synchronism between the application time and the plant demand (Carvalho et al., 2001; Soratto et al., 2004, 2014; Maia et al., 2012). Therefore, improving the N-use efficiency is desirable to increase yield, reduce production costs, and maintain environmental quality.

To increase the N-use efficiency, some authors have suggested the monitoring of $\mathrm{N}$ content in the leaf in different crops and with good accuracy with chlorophyll content indirect readings taken with a portable chlorophyll meter (Dwyer et al., 1995; Hussain et al., 2000; Silveira et al., 2003; Zhou \& Wang, 2003; Soratto et al., 2004; Barbosa Filho et al., 2008, 2009; Rosolem \& Mellis, 2010; Li et al., 2012; Maia et al., 2012, 2013). The relation between the relative chlorophyll index (RCI) - expressed by the amount of 650 and $940 \mathrm{~nm}$ wavelength light that passes through the leaf (transmittance) - and the $\mathrm{N}$ content in the leaves is mainly attributed to the fact that 50 to $70 \%$ of the total $\mathrm{N}$ in the leaves is part of the enzymes associated with chloroplasts (Chapman \& Barreto, 1997; Taiz \& Zeiger, 2013).

However, there are no established criteria for the use of a chlorophyll meter in common bean crop because several factors besides nutrient availability may influence the chlorophyll content in the leaves, such as the cultivar or grain type, maturation stage, age, and leaf node position. These factors have a direct impact on the RCI readings obtained with a chlorophyll meter (Hussain et al., 2000; Silveira et al., 2003; Zhou \& Wang, 2003; Li et al., 2012). According to Li et al. (2012), the best position of the leaf for the diagnosis of $\mathrm{N}$ in a plant is the position that is most sensitive to the nutrient variations in the environment because it allows deficiencies to be detected more accurately and as soon as possible.

To enable the use of RCI to manage $\mathrm{N}$ fertilization in bean crops through monitoring with a chlorophyll meter, Barbosa Filho et al. $(2008,2009)$ proposed the establishment of a reference area, that is, a plot that received $\mathrm{N}$ rates between 1.8 and 2.0 times the recommended rate for the crop (Hussain et al., 2000). The N sufficiency index (NSI) is calculated by the relationship between the RCI of the leaves of the crop plants on the farm $\left(\mathrm{RCI}_{\mathrm{Farm}}\right)$ and the $\mathrm{RCI}$ of the leaves of the plants in the reference area $\left(\mathrm{RCI}_{\text {Reference }}\right)$. In general, the application of $\mathrm{N}$ is indicated whenever the NSI of the plants is below $90 \%$ (Hussain et al., 2000; Barbosa Filho et al., 2008, 2009). Barbosa Filho et al. $(2008,2009)$ performed RCI readings on the second fully expanded trifoliate leaf, counting from the apex, at 28 days after emergence (DAE), and they could reduce the rate of $\mathrm{N}$ applied to the common bean 'Pérola', but with a significant reduction also in grain yield. This result indicates that possibly $90 \%$ NSI may lead to an $\mathrm{N}$ deficiency in the crop, or that the leaf used for monitoring may be less appropriate, or that monitoring started too late. However, Maia et al. (2012, 2013) reported that when using the first fully expanded trifoliate leaf, an NSI above $90 \%$ may lead to the application of higher rates of $\mathrm{N}$ and reduce the agronomic efficiency of the applied fertilizer.

Given the importance of providing $\mathrm{N}$ to the common bean crop at appropriate amounts, times, and locations (Carvalho et al., 2001), especially in the period before the beginning of flowering (Soratto et al., 2005), it is necessary to establish an accurate diagnostic leaf and the NSI values most suitable for the crop. When these data are obtained by indirect reading of the chlorophyll content, they are important for the definition of topdressing fertilization rates at a phenological stage of the crop when supplying the nutrient is still efficient to meet the plant requirements.

The objective of this work was to establish the diagnostic leaf and the NSI value most appropriate to estimate $\mathrm{N}$ requirement by the 'Pérola' common bean, by means of monitoring with a portable chlorophyll meter.

\section{Materials and Methods}

Three experiments were carried out under field conditions in the municipality of Botucatu, in state of São Paulo, Brazil (22 $51^{\prime} \mathrm{S}, 48^{\circ} 26^{\prime} \mathrm{W}$, at an altitude of $740 \mathrm{~m}$ ). According to Köppen's classification, the predominant climate in the region is Cwa, tropical 
altitude climate, characterized by a dry winter and hot and rainy summer. The soil of the experimental area was classified as Nitossolo Vermelho distroférrico (Santos et al., 2006), cultivated under a no-tillage system with corn/black oat/corn succession for approximately 12 years prior to the establishment of the experiments.

In all experiments, the experimental design was a randomized block design, with four replications. Each experimental unit had ten $6.0-\mathrm{m}$ long bean rows, spaced $0.45 \mathrm{~m}$ apart. For the evaluations, the four central rows were considered, and $0.5 \mathrm{~m}$ was excluded at the ends of each row. Water was supplied using a conventional sprinkler irrigation system (complementary irrigation), with the application of $7 \mathrm{~mm}$ of water in each irrigation, always during the first hours of the morning, according to the crop's needs.

An experiment was conducted during the rainy season of 2011 to define the diagnosis leaf that would be used to estimate the $\mathrm{N}$ demand of the crop with the $\mathrm{RCI}$ reading using a portable chlorophyll meter, named as the first step. Prior to this experiment, a soil sample was collected from the $0.0-0.20$-m layer, which had the following chemical characteristics: $34 \mathrm{~g} \mathrm{dm}^{-3}$ organic matter; $\mathrm{pH}\left(\mathrm{CaCl}_{2}\right) 4.7 ; 55 \mathrm{mg} \mathrm{dm}^{-3} \mathrm{P}_{\text {resin }} ; 3.9,27,10$, and $56 \mathrm{mmol}_{\mathrm{c}} \mathrm{dm}^{-3} \mathrm{~K}, \mathrm{Ca}, \mathrm{Mg}$, and $\mathrm{H}+\mathrm{Al}$, respectively; and base saturation (BS) of $42 \%$. The common bean crop was sown on $8 / 23 / 2011$ using 15 seeds per row meter. The plants emerged on $8 / 31 / 2011$. The treatments consisted of five $\mathrm{N}$ rates $\left(0,50,100,150\right.$, and $\left.200 \mathrm{~kg} \mathrm{ha}^{-1}\right)$ applied $1 / 5$ at sowing $+2 / 5$ at 10 days after emergence (DAE) $+2 / 5$ at $20 \mathrm{DAE}$; and RCI readings were performed on the first, second, and third fully expanded trifoliate leaves, counting from the apex. Basic fertilization at planting consisted of an application of $40 \mathrm{~kg} \mathrm{ha}^{-1} \mathrm{P}_{2} \mathrm{O}_{5}$ (single superphosphate) and $40 \mathrm{~kg} \mathrm{ha}^{-1} \mathrm{~K}_{2} \mathrm{O}$ (potassium chloride) in all treatments. The full flowering of the crop occurred at 48 DAE.

The RCI was determined using a portable chlorophyll meter, model SPAD-502 (Soil and Plant Analysis Development; Minolta Co., Osaka, Japan, 1989), with readings taken in the morning (8:00-10:00 a.m.), with the device being shaded by the body to avoid interference from sunlight. The readings began at 14 DAE, after which they were performed weekly, that is, at 21, 28, and $35 \mathrm{DAE}$, with sampling of five plants per experimental unit. In each evaluation, two readings per leaflet were performed for all the diagnostic leaves evaluated, along the leaf blade and avoiding the ribs. Immediately after determination of the RCI, the leaves were collected, washed with distilled water, dried in a forced-air oven at $65^{\circ} \mathrm{C}$ for 72 hours, and ground for analysis of the total $\mathrm{N}$ content (Malavolta et al., 1997).

The grain yield was determined by harvesting the plants in the useful area of each experimental unit, at 101 DAE. After being uprooted, the plants were dried in the sun and then mechanically threshed. The grains, after shaking, were weighed, and the yield was calculated in $\mathrm{kg} \mathrm{ha}^{-1}$, after being corrected for a water content of $130 \mathrm{~g} \mathrm{~kg}^{-1}$.

In the second step of the work, using a chlorophyll meter, it was sought to define the NSI $\left(\mathrm{RCI}_{\mathrm{Farm}} /\right.$ $\mathrm{RCI}_{\text {Reference }} \times 100$ ) value that is most appropriate for use in determining the $\mathrm{N}$ requirements for the crop. The diagnosis leaf established in the first step was used. Two experiments were carried out: one in the dry season and the other in the rainy season in 2012. Before each experiment began, soil sampling for chemical analysis was conducted in the $0-0.20-\mathrm{m}$ layer. In the area used in the dry season, soil analysis showed the following results: $24 \mathrm{~g} \mathrm{dm}^{-3}$ organic matter; $\mathrm{pH}\left(\mathrm{CaCl}_{2}\right)$ 4.4; $20 \mathrm{mg} \mathrm{dm}^{-3} \mathrm{P}_{\text {resin }}$; $\mathrm{K}, \mathrm{Ca}, \mathrm{Mg}$ and $\mathrm{H}+\mathrm{Al}: 1.3,19,6$, and $54 \mathrm{mmol}_{\mathrm{c}} \mathrm{dm}^{-3}$, respectively; and BS of $33 \%$. In the area used in the rainy season, the soil analysis showed the following results: $35 \mathrm{~g} \mathrm{dm}^{-3}$ organic matter; $\mathrm{pH}\left(\mathrm{CaCl}_{2}\right)$ 5.0; $26 \mathrm{mg} \mathrm{dm}^{-3} \mathrm{P}_{\text {resin }} ; \mathrm{K}, \mathrm{Ca}, \mathrm{Mg}$, and $\mathrm{H}+\mathrm{Al}: 1.2,23,8$, and $36 \mathrm{mmol}_{\mathrm{c}} \mathrm{dm}^{-3}$, respectively; and BS of $48 \%$. Seeds were sown on $02 / 29 / 2012$ and $08 / 20 / 2012$ at 15 seeds per row meter. Seedlings emerged on 03/07/2012 and $08 / 29 / 2012$ in the dry and rainy seasons, respectively.

The treatments consisted of six $\mathrm{N}$ management regimes: $\mathrm{M} 1,40 \mathrm{~kg} \mathrm{ha}^{-1} \mathrm{~N}$ at sowing $+80 \mathrm{~kg} \mathrm{ha}^{-1}$ at $10 \mathrm{DAE}+80 \mathrm{~kg} \mathrm{ha}^{-1}$ at $20 \mathrm{DAE}$ (reference); M2, $20 \mathrm{~kg} \mathrm{ha}^{-1}$ at sowing $+40 \mathrm{~kg} \mathrm{ha}^{-1}$ at $10 \mathrm{DAE}+40 \mathrm{~kg} \mathrm{ha}^{-1}$ at $20 \mathrm{DAE}$ (recommended rate); M3, $20 \mathrm{~kg} \mathrm{ha}^{-1}$ at sowing $+30 \mathrm{~kg} \mathrm{ha}^{-1}$ at topdressing when chlorophyll meter readings indicated $\mathrm{NSI}<96 \%$; $44,20 \mathrm{~kg} \mathrm{ha}^{-1}$ at sowing $+30 \mathrm{~kg} \mathrm{ha}^{-1}$ at topdressing when readings indicated $\mathrm{NSI}<93 \%$; M5, $20 \mathrm{~kg} \mathrm{ha}^{-1}$ at sowing $+30 \mathrm{~kg} \mathrm{ha}^{-1}$ at topdressing when readings indicated $\mathrm{NSI}<90 \%$; and M6, control without $\mathrm{N}$ application. The rate in treatment M2 was defined based on the recommendation of Ambrosano et al. (1997), and the areas were considered to have a high probability of response to $\mathrm{N}$ fertilization and an estimated yield of 3,500 to $4,500 \mathrm{~kg} \mathrm{ha}^{-1}$. The basic fertilization at planting consisted of $60 \mathrm{~kg} \mathrm{ha}^{-1}$ 
of $\mathrm{P}_{2} \mathrm{O}_{5}$ (single superphosphate) and $40 \mathrm{~kg} \mathrm{ha}^{-1} \mathrm{~K}_{2} \mathrm{O}$ (potassium chloride) in all treatments.

In the two growing seasons, NSI monitoring through the RCI readings was performed at 14, 21, 28 , and $35 \mathrm{DAE}$ in the diagnostic leaf defined in the first step. When the NSI was greater than or equal to $96 \%$ (M3), $93 \%$ (M4), or $90 \%$ (M5), $\mathrm{N}$ was not applied at topdressing, and when the NSI was lower than these values, the rates established for each $\mathrm{N}$ treatment were applied approximately 24 hours after RCI determination (Table 1).

At the time of full flowering, which occurred at 35 DAE in the dry season and at $42 \mathrm{DAE}$ in the rainy season, the shoot dry matter (DM) was evaluated in ten plants per plot, which were washed with distilled water, dried in a forced-air oven at $65^{\circ} \mathrm{C}$ for 72 hours, and weighed. The material used to determine the shoot DM was also used for the analysis of the total $\mathrm{N}$ content (Malavolta et al., 1997). Subsequently, the N contents were multiplied by the DM, and by the plant population that was measured in each plot to calculate the amount of $\mathrm{N}$ accumulated. The final population of plants was determined on the harvest eve, in two 3-m-long rows within the useful area, in each experimental unit. The grain yield was determined in the same manner as in the first step, at 91 DAE in the dry season and at 85 DAE in the rainy season.

The data obtained in the first step were subjected to the analysis of variance using the F-test. The effects of

Table 1. Time of topdressing application and total $\mathrm{N}$ applied in each treatment and growing season of 'Pérola' common bean (Phaseolus vulgaris), in the dry and rainy seasons of 2012, in an experiment to determine the $\mathrm{N}$ sufficiency index (NSI) value most appropriate for indicating the need for application of $\mathrm{N}$ to the crop.

\begin{tabular}{lcccccc}
\hline N treatment $^{(1)}$ & \multicolumn{2}{c}{ Time of application (DAE) } & & \multicolumn{2}{c}{ Total N applied $\left(\mathrm{kg} \mathrm{ha}^{-1}\right)$} \\
\cline { 2 - 3 } \cline { 5 - 6 } & Dry & Rainy & & Dry & Rainy \\
\hline M1 & 10 and 20 & 10 and 20 & & 200 & 200 \\
M2 & 10 and 20 & 10 and 20 & & 100 & 100 \\
M3 & 22 & 36 & & 50 & 50 \\
M4 & 22 & 36 & & 50 & 50 \\
M5 & - & - & & 20 & 20 \\
M6 & - & - & & 0 & 0 \\
\hline
\end{tabular}

(1) $\mathrm{M} 1,40 \mathrm{~kg} \mathrm{ha}^{-1} \mathrm{~N}$ at sowing $+80 \mathrm{~kg} \mathrm{ha}^{-1}$ at 10 days after emergence $(\mathrm{DAE})+80 \mathrm{~kg} \mathrm{ha}^{-1}$ at $20 \mathrm{DAE}$ (reference); M2, $20 \mathrm{~kg} \mathrm{ha}^{-1}$ at sowing +40 $\mathrm{kg} \mathrm{ha}^{-1}$ at $10 \mathrm{DAE}+40 \mathrm{~kg} \mathrm{ha}^{-1}$ at $20 \mathrm{DAE}$ (recommended rate); M3, $20 \mathrm{~kg}$ $\mathrm{ha}^{-1}$ at sowing $+30 \mathrm{~kg} \mathrm{ha}^{-1}$ when NSI $<96 \% ; \mathrm{M} 4,20 \mathrm{~kg} \mathrm{ha}^{-1}$ at sowing +30 $\mathrm{kg} \mathrm{ha}^{-1}$ when NSI $<93 \%$; M5, $20 \mathrm{~kg} \mathrm{ha}^{-1}$ at sowing $+30 \mathrm{~kg} \mathrm{ha}^{-1}$ when NSI $<90 \%$; and M6, without application of N.
$\mathrm{N}$ rates were evaluated by regression analysis. Linear correlations were also established as a measure of dependence between the RCI values and the $\mathrm{N}$ content in each leaf collected at the time of the chlorophyll meter reading, as well as between the RCI values and leaf $\mathrm{N}$ content with grain yield. The data obtained in the second step were subjected to the Anova using the F-test. The means of the treatments were compared by Tukey's test, at $5 \%$ probability.

\section{Results and Discussion}

In the first step of the work, an effect of $\mathrm{N}$ rates on the RCI values obtained with the chlorophyll meter was observed, both in the youngest and most mature leaves, in all the evaluation periods (Table 2). The first leaf presented linear responses to the application of $\mathrm{N}$ in the evaluations performed at 14 and $28 \mathrm{DAE}$, and quadratic responses at 28 and $35 \mathrm{DAE}$. The RCI of the second leaf presented linear behavior at 21 and $28 \mathrm{DAE}$, and quadratic behavior at $35 \mathrm{DAE}$. The third leaf presented linear responses in the assessments at 28 and 35 DAE. These results indicate that, besides the availability of $\mathrm{N}$, the different leaves used probably had morphophysiological differences in thickness, pigment content, and internal structure, which affected the spectral properties of the leaf, with effects on the RCI values. In rice, Zhou \& Wang (2003) found a large difference between the younger and the more physiologically mature leaves in the sensitivity of the $\mathrm{RCI}$ response to variation in $\mathrm{N}$ availability. Moreover, $\mathrm{Li}$ et al. (2012) reported that the sensitivity of the RCI values to the applied $\mathrm{N}$ is an important factor in determining the best diagnostic leaf.

The $\mathrm{N}$ content was also increased by the $\mathrm{N}$ rates except for the evaluation of the second fully expanded leaf at 28 DAE (Table 2). Notably, even in the absence of $\mathrm{N}$ fertilization, the values obtained were within or above the concentration range of 30 to $50 \mathrm{~g} \mathrm{~kg}^{-1}$, indicated by Ambrosano et al. (1997) as appropriate for a common bean crop. The grain yield increased linearly with the application of $\mathrm{N}$ up to the maximum rate of $200 \mathrm{~kg} \mathrm{ha}^{-1}$. Therefore, even with $\mathrm{N}$ levels above the critical level, grain production responded to $\mathrm{N}$ fertilization, which has already been reported in other studies (Soratto et al., 2004; Crusciol et al., 2007) and indicates a possible inadequacy of that sufficiency 
range to the current production systems used for the crop.

There were positive linear correlations between the RCI values and the $\mathrm{N}$ contents in all leaves and evaluation times (Table 3). This is explained by the fact that 50 to $70 \%$ of the total $\mathrm{N}$ of the leaves is a component of chlorophyll (Chapman \& Barreto, 1997; Taiz \& Zeiger, 2013). The highest correlations, before common bean flowering, were observed in the older leaves, namely, in the second fully expanded leaf in the evaluation at $21 \mathrm{DAE}$; and in the third fully expanded leaf in the evaluations at 28 and 35 DAE. This result was probably due to the greater variations observed in the RCI values and in the $\mathrm{N}$ contents with the $\mathrm{N}$ rates applied (Table 2). As plants usually prioritize the development of young tissues, they mobilize the $\mathrm{N}$ from the older leaves to the younger ones, especially when they are deficient in the nutrient, which avoids large variations in $\mathrm{N}$ contents in these tissues. In addition, younger leaves commonly present higher levels of
$\mathrm{NO}_{3}-\mathrm{N}-$ a form not associated with the chlorophyll molecule -, which causes the evaluation of the nutritional status of these plants, using the chlorophyll meter in these leaves, to be impaired (Dwyer et al., 1995).

In addition to the higher correlations between the $\mathrm{RCI}$ and $\mathrm{N}$ content observed in the third fully expanded leaf, the RCI determined on this leaf at 28 DAE also showed a higher correlation with grain yield (Table 3). Therefore, this correlation was used in the second step of the work, which sought to use the chlorophyll meter to define the most appropriate NSI value to indicate the need for application of $\mathrm{N}$ in the crop. If the third fully expanded leaf is not developed yet, the oldest leaf of the plant should be used for the RCI monitoring.

In the dry season, the NSIs of treatments based on the RCI values determined at 14 DAE presented values of $96.1 \%$ in $\mathrm{M} 3,93.2 \%$ in $\mathrm{M} 4$, and $94.1 \%$ in M5, indicating that there was no need to apply $\mathrm{N}$ as topdressing in these treatments (Figure $1 \mathrm{C}$ ). At

Table 2. Relative chlorophyll indexes (RCI) and $\mathrm{N}$ contents determined in the first, second, and third fully expanded leaves, counting from the apex, evaluated with a portable chlorophyll meter at 14, 21, 28, and 35 days after emergence (DAE) and the grain yield of the 'Pérola' common bean (Phaseolus vulgaris) as a function of the $\mathrm{N}$ rates used in the experiment to determine the most appropriate diagnostic leaf in the 2011 rainy season.

\begin{tabular}{|c|c|c|c|c|c|c|c|c|c|c|}
\hline \multirow[t]{2}{*}{ Time } & \multirow{2}{*}{$\begin{array}{c}\text { Leaf } \\
\text { position }\end{array}$} & \multicolumn{5}{|c|}{$\mathrm{N}$ rates $\left(\mathrm{kg} \mathrm{ha}^{-1}\right)$} & \multirow{2}{*}{$\begin{array}{l}\text { CV } \\
(\%)\end{array}$} & \multirow[t]{2}{*}{ Equation } & \multirow[t]{2}{*}{$\mathrm{R}^{2}$} & \multirow[t]{2}{*}{ p-value } \\
\hline & & 0 & 50 & 100 & 150 & 200 & & & & \\
\hline \multicolumn{11}{|c|}{ Relative chlorophyll indexes (SPAD) } \\
\hline $14 \mathrm{DAE}$ & $1^{\text {st }}$ & 31.8 & 34.2 & 37.2 & 38.3 & 39.4 & 6.6 & $y=32.30+0.038 x$ & $0.95 * *$ & 0.0041 \\
\hline \multirow{2}{*}{$21 \mathrm{DAE}$} & $1^{\text {st }}$ & 34.2 & 36.2 & 34.9 & 39.0 & 42.3 & 3.5 & $y=34.32+0.037 x$ & $0.96^{* *}$ & $<0.0001$ \\
\hline & $2^{\text {nd }}$ & 40.3 & 41.3 & 41.6 & 43.1 & 48.4 & 4.1 & $y=39.95+0.035 x$ & $0.80 * *$ & 0.0003 \\
\hline \multirow{3}{*}{$28 \mathrm{DAE}$} & $1^{\text {st }}$ & 33.8 & 36.8 & 37.0 & 36.2 & 36.8 & 2.8 & $y=33.98+0.042 x-0.0001 x^{2}$ & $0.85^{*}$ & 0.0048 \\
\hline & $2^{\text {nd }}$ & 42.5 & 45.4 & 44.9 & 45.3 & 46.5 & 1.9 & $y=43.34+0.015 x$ & $0.72 * *$ & 0.0004 \\
\hline & $3^{\text {rd }}$ & 45.2 & 47.7 & 48.5 & 49.5 & 51.3 & 3.2 & $y=45.63+0.028 x$ & $0.96 * *$ & 0.0015 \\
\hline \multirow{3}{*}{35 DAE } & $1^{\text {st }}$ & 37.8 & 37.6 & 39.0 & 39.5 & 40.5 & 2.3 & $\mathrm{y}=37.42+0.014 x$ & $0.91 * *$ & 0.0039 \\
\hline & $2^{\text {nd }}$ & 42.8 & 31.2 & 42.2 & 42.8 & 43.7 & 1.7 & $y=42.52-0.0195 x+0.0001 x^{2}$ & $0.78 * *$ & 0.0034 \\
\hline & $3^{\text {rd }}$ & 37.7 & 36.4 & 46.4 & 47.3 & 48.6 & 2.0 & $y=47.60-0.0032 x+0.0001 x^{2}$ & $0.97 * *$ & 0.0180 \\
\hline \multicolumn{11}{|c|}{ Leaf $\mathrm{N}$ content $\left(\mathrm{g} \mathrm{kg}^{-1}\right)$} \\
\hline $14 \mathrm{DAE}$ & $1^{\text {st }}$ & 40.6 & 45.8 & 47.7 & 49.2 & 52.7 & 5.0 & $y=41.70+0.005 x$ & $0.95 * *$ & 0.0002 \\
\hline \multirow{2}{*}{$21 \mathrm{DAE}$} & $1^{\text {st }}$ & 44.9 & 48.5 & 49.0 & 50.6 & 50.8 & 2.4 & $y=46.14+0.024 x$ & $0.76^{* *}$ & 0.0001 \\
\hline & $2^{\text {nd }}$ & 38.7 & 41.7 & 44.7 & 47.8 & 48.7 & 3.4 & $y=39.08+0.052 x$ & $0.97 * *$ & $<0.0001$ \\
\hline \multirow{3}{*}{$28 \mathrm{DAE}$} & $1^{\text {st }}$ & 50.5 & 50.8 & 51.5 & 52.4 & 53.3 & 2.4 & $y=50.26+0.014 x$ & $0.98 * *$ & 0.0365 \\
\hline & $2^{\text {nd }}$ & 49.3 & 51.3 & 52.1 & 52.0 & 52.2 & 3.5 & ns & - & 0.2086 \\
\hline & $3^{\text {rd }}$ & 41.4 & 52.4 & 44.6 & 46.0 & 45.4 & 4.3 & $y=41.58+0.0236 x$ & $0.87 * *$ & 0.0191 \\
\hline \multirow{3}{*}{$35 \mathrm{DAE}$} & $1^{\text {st }}$ & 51.4 & 51.2 & 50.5 & 56.1 & 55.2 & 1.8 & $y=51.09-0.033 x+0.0001 x^{2}$ & $0.65^{*}$ & $<0.0001$ \\
\hline & $2^{\text {nd }}$ & 42.8 & 42.7 & 41.8 & 44.4 & 48.7 & 2.9 & $y=43.13-0.043 x+0.0004 x^{2}$ & $0.96^{* *}$ & $<0.0001$ \\
\hline & $3^{\text {rd }}$ & 40.2 & 40.7 & 40.5 & 41.6 & 45.4 & 3.5 & $\mathrm{y}=40.55-0.022 \mathrm{x}+0.0002 \mathrm{x}^{2}$ & $0.94 *$ & 0.0016 \\
\hline \multicolumn{11}{|c|}{ Grain yield $\left(\mathrm{kg} \mathrm{ha}^{-1}\right)$} \\
\hline End of cycle & & 3,210 & 3,664 & 3,863 & 4,026 & 4,018 & 7.6 & $\mathrm{y}=3,360.80+3.95 \mathrm{x}$ & $0.85 * *$ & 0.0089 \\
\hline
\end{tabular}

${ }^{n s}$ Nonsignificant. * and **Significant by the $\mathrm{F}$ test, at $5 \%$ and $1 \%$ probability, respectively. 
21 DAE, M3 and M4 treatments presented 90\% and 91\% NSI, respectively, indicating the need for the first application of $\mathrm{N}$ in topdressing (Table 1). Treatment M5 did not show NSI below the defined minimum limit and did not receive topdressing application. At 28 and 35 DAE, the RCI values observed in the reference treatment (M1) were similar to those of the other treatments with $\mathrm{N}$ application (M2, M3, M4, and M5). The NSI values of the treatments M3, M4, and M5 were higher than the pre-established indices for each of these treatments (M3 $=96 \%$, M4 $=93 \%$, and M5 $=90 \%$, which precluded the need for topdressing fertilization on those dates.

In the rainy season, at $14 \mathrm{DAE}$, the RCI values observed in the reference treatment (M1) were similar to those observed in the other $\mathrm{N}$ treatments (Figure 1), and the NSI values of the treatments M3, M4, and

Table 3. Simple linear correlation coefficients of the relative chlorophyll index (RCI) and of the $\mathrm{N}$ content determined in the first, second, and third fully expanded leaves, counting from the apex, at 14, 21, 28, and 35 days after emergence (DAE), with grain yield of the 'Pérola' common bean (Phaseolus vulgaris) as a function of $\mathrm{N}$ rates used in the experiment to determine the most appropriate diagnosis leaf, in the rainy season in 2011.

\begin{tabular}{|c|c|c|c|}
\hline Leaf position & Variable & Leaf $\mathrm{N}$ content & Grain yield \\
\hline \multirow{3}{*}{$1^{\text {st }}$} & & $14 \mathrm{DAE}$ & \\
\hline & RCI & $0.68 * *$ & $0.44 *$ \\
\hline & Leaf $\mathrm{N}$ content & - & $0.72^{* * *}$ \\
\hline \multirow{3}{*}{$1^{\text {st }}$} & & $21 \mathrm{DAE}$ & \\
\hline & RCI & $0.79 * *$ & $0.59 * *$ \\
\hline & Leaf $N$ content & - & $0.61 * *$ \\
\hline \multirow{2}{*}{$2^{\text {nd }}$} & RCI & $0.80 * *$ & $0.48^{*}$ \\
\hline & Leaf $N$ content & - & $0.64 * *$ \\
\hline \multirow{3}{*}{$1^{\text {st }}$} & & $28 \mathrm{DAE}$ & \\
\hline & RCI & $0.75^{* *}$ & $0.61 * *$ \\
\hline & Leaf $\mathrm{N}$ content & - & ns \\
\hline \multirow{2}{*}{$2^{\text {nd }}$} & $\mathrm{RCI}$ & $0.80^{* * *}$ & $0.56^{*}$ \\
\hline & Leaf $\mathrm{N}$ content & - & ns \\
\hline \multirow{3}{*}{$3^{\text {rd }}$} & $\mathrm{RCI}$ & $0.89^{* * *}$ & $0.64 * *$ \\
\hline & Leaf $\mathrm{N}$ content & - & ns \\
\hline & & $35 \mathrm{DAE}$ & \\
\hline \multirow{2}{*}{$1^{\text {st }}$} & RCI & $0.72 * * *$ & ns \\
\hline & Leaf $\mathrm{N}$ content & - & ns \\
\hline \multirow{2}{*}{$2^{\text {nd }}$} & RCI & $0.77 * * *$ & ns \\
\hline & Leaf $\mathrm{N}$ content & - & ns \\
\hline \multirow{2}{*}{$3^{\text {rd }}$} & RCI & $0.81 * * *$ & $\mathrm{~ns}$ \\
\hline & Leaf $N$ content & - & ns \\
\hline
\end{tabular}

${ }^{n s}$ Nonsignificant. *, **, and $* * *$ Significant by the t-test at 5,1 and $0.1 \%$ probability, respectively.
M5 were higher than the pre-established NSIs, which precluded the need for topdressing fertilization on that date. At 21 and $28 \mathrm{DAE}$, the M3, M4, and M5 treatments did not present an index below the defined minimum limit and, therefore, no application of $\mathrm{N}$ was carried out as topdressing. The NSI values at $21 \mathrm{DAE}$ were $100 \%$ in $\mathrm{M} 3,98 \%$ in M4, and $99.3 \%$ in M5; at $28 \mathrm{DAE}$, these values were $97 \%$ in M3, 96.3\% in M4, and $95.8 \%$ in M5. At 35 DAE, M3 and M4 showed an NSI of $93 \%$ and $87.3 \%$, respectively, thus indicating the need for the first application of $\mathrm{N}$ in topdressing (Table 1). The M5 treatment $(\mathrm{NSI}<90 \%)$ did not present an NSI below the pre-established value on any of the evaluation dates.

During the evaluation period, in the two growing seasons, the RCI values of the treatment without application of $\mathrm{N}$ (M6) were very close to those obtained in the $\mathrm{N}$-fertilized plots (Figures $1 \mathrm{~A}$ and $\mathrm{B}$ ). This result may have been due to the mineralization process of the $\mathrm{N}$ present in the plant residues or the soil organic matter.

The final population size of the plants was not influenced by the treatments, averaging 178,300 plants per hectare in the dry season and 271,100 plants per hectare in the rainy season. However, an effect of the $\mathrm{N}$ treatments was observed on the shoot DM production in both growing seasons evaluated (Table 4). In the dry season, treatments M1 and M2 provided the highest DM production levels. In the rainy season, however, treatments M1 and M5 provided the highest DM. Crusciol et al. (2007) and Soratto et al. (2014) reported an increase in the DM of the common bean with the application of $\mathrm{N}$ in a no-tillage system.

However, for shoot $\mathrm{N}$ contents, treatments had a significant effect only in the dry season, with the highest value recorded in treatment M2, which nevertheless only differed from M4 (Table 4). Notably, the variation in $\mathrm{N}$ content in the shoot is simultaneously influenced by the uptake of the nutrient by the plant and by the dilution effect resulting from the increased DM production.

The amount of $\mathrm{N}$ accumulated in the shoot was affected by the treatments studied in the two growing seasons. In the dry season, treatments M1, M2, and M3 had the highest accumulated $\mathrm{N}$ values, due to both the higher DM production levels and the higher levels of $\mathrm{N}$ in the shoot. In the rainy season, the greatest accumulation of $\mathrm{N}$ in the shoot was observed 
in treatment M1, but this accumulation was only significantly different from those in the M4 and M6 treatments.

The grain yield was not significantly influenced by the $\mathrm{N}$ treatments in any season (Table 4). High yields $\left(2,813\right.$ and $\left.3,270 \mathrm{~kg} \mathrm{ha}^{-1}\right)$ were obtained even without the application of $\mathrm{N}$ at topdressing, which was probably related to the lower temperature oscillation and higher soil water content that resulted from the high amount of straw present on the soil surface under the no-tillage system (Soratto et al., 2013a). For Kluthcouski et al.
(2006), areas under no-tillage systems for prolonged periods receive a highly significant $\mathrm{N}$ supply due to the nutrient cycling in the system, which would allow good grain yields in the common bean crop with application of only small rates of $\mathrm{N}$ at sowing.

However, in both growing seasons, $\mathrm{N}$ management by monitoring with a portable chlorophyll meter and with NSI $<90 \%$ (M5) provides savings of $180 \mathrm{~kg} \mathrm{ha}^{-1}$ of $\mathrm{N}$, compared with the reference treatment (M1), or of $80 \mathrm{~kg} \mathrm{ha}^{-1}$ of $\mathrm{N}$, compared with the treatment based on the management (M2) recommended by Ambrosano
Dry season
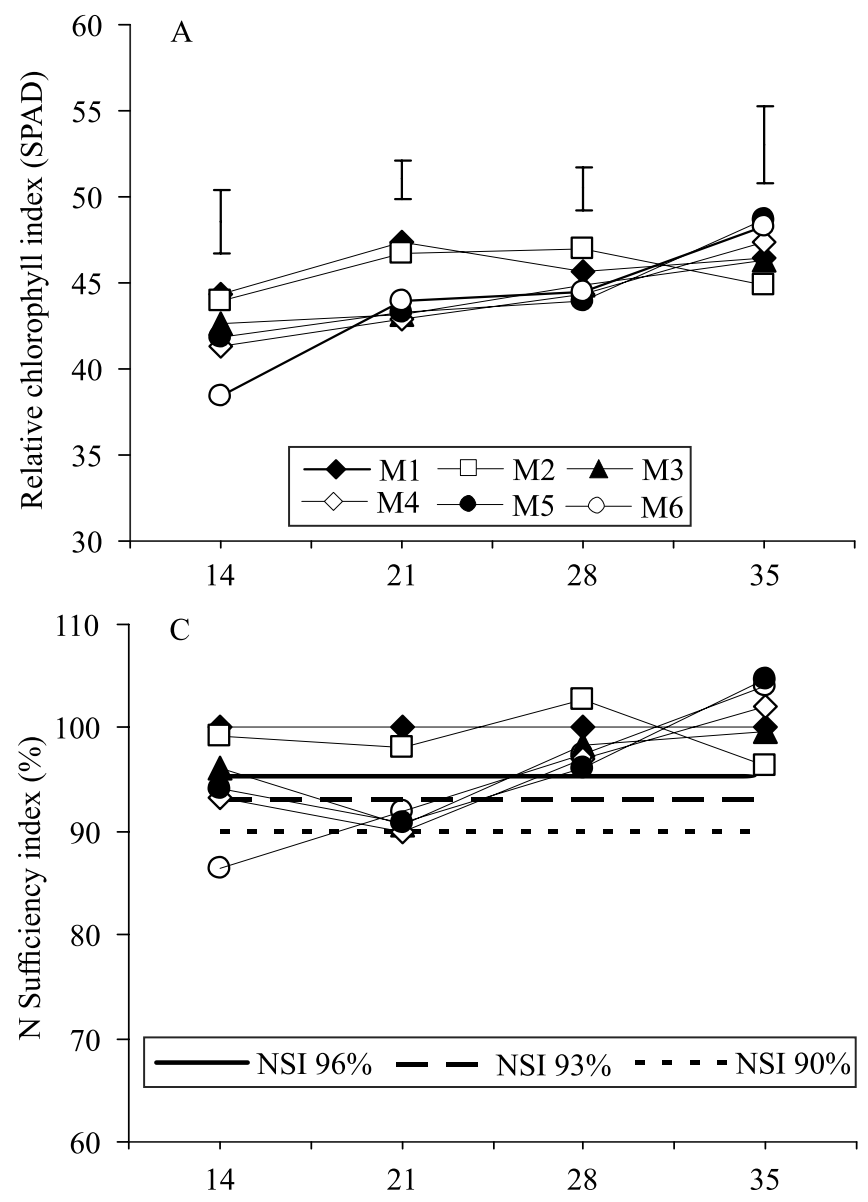

Days after emergence
Rainy season
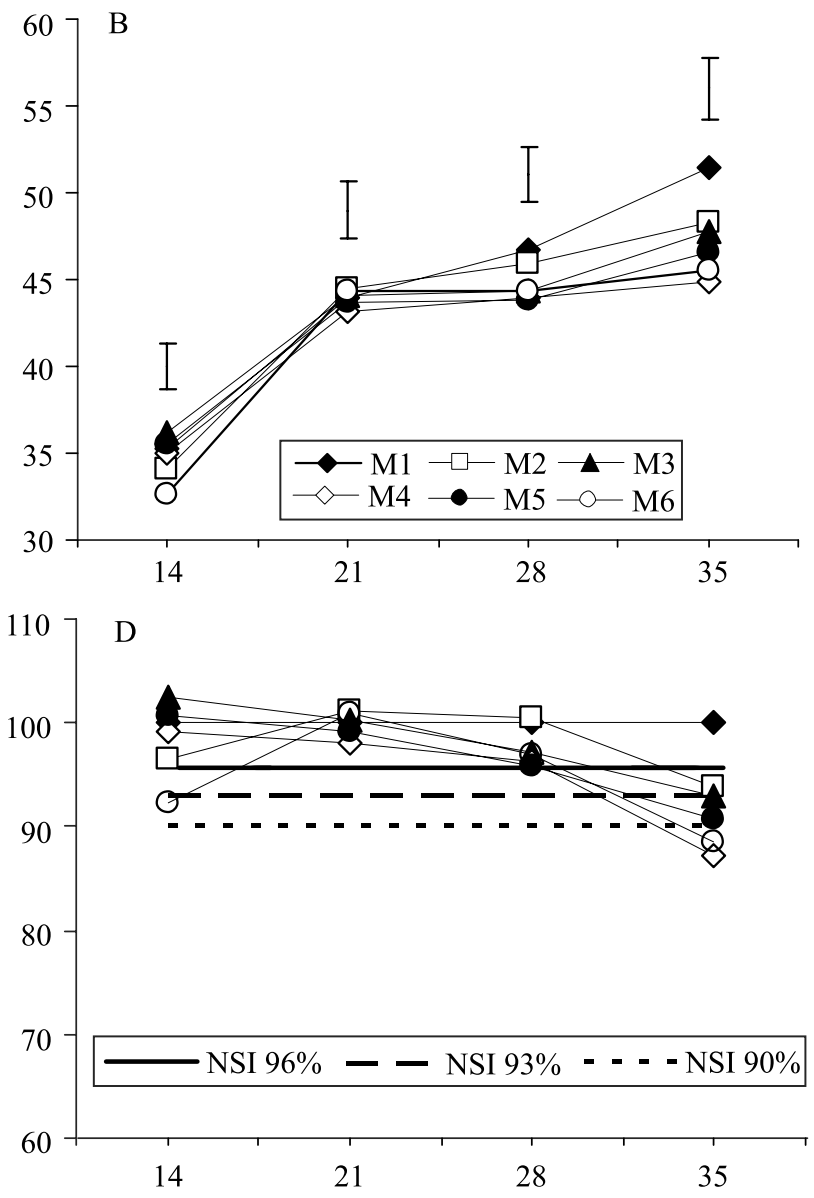

Days after emergence

Figure 1. Relative chlorophyll index (A and $\mathrm{B}$ ) and $\mathrm{N}$ sufficiency index ( $\mathrm{C}$ and $\mathrm{D}$ ) in the 'Pérola' common bean (Phaseolus vulgaris), obtained in the experiment to determine the need for $\mathrm{N}$ application in the 2012 dry (A and $\mathrm{C}$ ) and rainy (B and D) seasons, on different days after emergence and as a function of the $\mathrm{N}$ topdressing fertilization treatment. M1, $40 \mathrm{~kg} \mathrm{ha}^{-1} \mathrm{~N}$ at sowing $+80 \mathrm{~kg} \mathrm{ha}^{-1}$ at 10 days after emergence (DAE) $+80 \mathrm{~kg} \mathrm{ha}^{-1}$ at $20 \mathrm{DAE}$ (reference); M2, $20 \mathrm{~kg} \mathrm{ha}^{-1}$ at sowing +40 $\mathrm{kg} \mathrm{ha}^{-1}$ at $10 \mathrm{DAE}+40 \mathrm{~kg} \mathrm{ha}^{-1}$ at $20 \mathrm{DAE}$ (recommended rate); M3, $20 \mathrm{~kg} \mathrm{ha}^{-1}$ at sowing $+30 \mathrm{~kg} \mathrm{ha}^{-1}$ when NSI $<96 \%$; M4, $20 \mathrm{~kg} \mathrm{ha}^{-1}$ at sowing $+30 \mathrm{~kg} \mathrm{ha}^{-1}$ when $\mathrm{NSI}<93 \%$; M5, $20 \mathrm{~kg} \mathrm{ha}^{-1}$ at sowing $+30 \mathrm{~kg} \mathrm{ha}^{-1}$ when $\mathrm{NSI}<90 \%$; and M6, without application of $\mathrm{N}$. Vertical bars indicate the least significant difference by Tukey's test, at $5 \%$ probability. 
Table 4. Dry matter (DM), N content, and amount of N accumulated in the shoot in stage R6 (full bloom), as well as grain yield of the 'Pérola' common bean (Phaseolus vulgaris) as a function of the $\mathrm{N}$ treatments in the experiment to determine the N sufficiency index (NSI) value most appropriate for indicating the need for application of $\mathrm{N}$ in the crop in the dry and rainy seasons in $2012^{(1)}$.

\begin{tabular}{|c|c|c|c|c|c|c|c|c|}
\hline \multirow[t]{2}{*}{$\mathrm{N}$ treatment $^{(2)}$} & \multicolumn{2}{|c|}{ Shoot DM $\left(\right.$ g plant $\left.^{-1}\right)$} & \multicolumn{2}{|c|}{$\mathrm{N}$ content in shoot DM $\left(\mathrm{g} \mathrm{kg}^{-1}\right)$} & \multicolumn{2}{|c|}{$\mathrm{N}$ accumulated in the shoot $\left(\mathrm{kg} \mathrm{ha}^{-1}\right)$} & \multicolumn{2}{|c|}{ Grain yield $\left(\mathrm{kg} \mathrm{ha}^{-1}\right)$} \\
\hline & Dry & Rainy & Dry & Rainy & Dry & Rainy & Dry & Rainy \\
\hline$\overline{\mathrm{M} 1}$ & $13.8 \mathrm{a}$ & $15.7 \mathrm{a}$ & $34.3 \mathrm{ab}$ & $31.4 \mathrm{a}$ & $88.8 \mathrm{a}$ & $131.1 \mathrm{a}$ & $3,120 \mathrm{a}$ & $3,568 \mathrm{a}$ \\
\hline M2 & $13.5 \mathrm{a}$ & $13.1 \mathrm{bc}$ & $34.1 \mathrm{ab}$ & $28.4 \mathrm{a}$ & $85.4 \mathrm{a}$ & $103.4 \mathrm{ab}$ & $2,959 \mathrm{a}$ & $3,083 \mathrm{a}$ \\
\hline M3 & $11.3 \mathrm{ab}$ & $12.4 \mathrm{c}$ & $36.1 \mathrm{a}$ & $31.6 \mathrm{a}$ & $76.4 \mathrm{ab}$ & $106.5 \mathrm{ab}$ & $2,740 \mathrm{a}$ & $2,989 \mathrm{a}$ \\
\hline M4 & $10.1 \mathrm{bc}$ & $11.3 \mathrm{c}$ & $28.0 \mathrm{~b}$ & $33.1 \mathrm{a}$ & $47.0 \mathrm{c}$ & $97.6 \mathrm{~b}$ & $2,796 \mathrm{a}$ & $2,987 \mathrm{a}$ \\
\hline M5 & $9.1 \mathrm{bc}$ & $15.1 \mathrm{ab}$ & $35.0 \mathrm{ab}$ & $27.9 \mathrm{a}$ & $60.9 \mathrm{bc}$ & $117.3 \mathrm{ab}$ & $2,676 \mathrm{a}$ & $3,088 \mathrm{a}$ \\
\hline M6 & $8.7 \mathrm{c}$ & $11.3 \mathrm{c}$ & $29.3 \mathrm{ab}$ & $30.4 a$ & $46.8 \mathrm{c}$ & $93.5 \mathrm{~b}$ & $2,813 \mathrm{a}$ & $3,270 \mathrm{a}$ \\
\hline CV (\%) & 11.3 & 7.4 & 10.6 & 5.3 & 15.4 & 13.1 & 10.5 & 12.5 \\
\hline
\end{tabular}

(1) Means followed by equal letters, in the columns, do not differ by Tukey's test, at $5 \%$ probability. ${ }^{(2)} \mathrm{M} 1,40 \mathrm{~kg} \mathrm{ha}^{-1} \mathrm{~N}$ at sowing $+80 \mathrm{~kg}$ ha-1 at $10 \mathrm{days}^{2}$ after emergence (DAE) $+80 \mathrm{~kg} \mathrm{ha}^{-1}$ at $20 \mathrm{DAE}$ (reference); M2, $20 \mathrm{~kg} \mathrm{ha}^{-1}$ at sowing $+40 \mathrm{~kg} \mathrm{ha}^{-1}$ at $10 \mathrm{DAE}+40 \mathrm{~kg}$ ha ${ }^{-1}$ at $20 \mathrm{DAE}$ (recommended rate); M3, $20 \mathrm{~kg} \mathrm{ha}^{-1}$ at sowing $+30 \mathrm{~kg} \mathrm{ha}^{-1}$ when NSI $<96 \%$; M4, $20 \mathrm{~kg} \mathrm{ha}^{-1}$ at sowing $+30 \mathrm{~kg} \mathrm{ha}^{-1}$ when NSI $<93 \%$; M5, $20 \mathrm{~kg}$ ha ${ }^{-1}$ at sowing $+30 \mathrm{~kg} \mathrm{ha}{ }^{-1}$ when $\mathrm{NSI}<90 \%$; and M6, without application of N. CV, coeficient of variation.

et al. (1997) (Table 1). Therefore, monitoring with a portable chlorophyll meter can prevent the excessive application of $\mathrm{N}$ at topdressing in the common bean crop.

\section{Conclusions}

1. The readings of the relative chlorophyll index (RCI) with a portable chlorophyll meter in the second fully expanded leaf, in the initial stage of the 'Pérola' common bean (Phaseolus vulgaris) cycle, and in the third leaf in later stages, provide the best correlations with the leaf $\mathrm{N}$ content and are, therefore, more accurate in estimating the $\mathrm{N}$ requirements of the crop before the flowering.

2. An $\mathrm{N}$ sufficiency index (NSI) of $90 \%$ is more efficient than those of 93 and $96 \%$, in determining when to apply $\mathrm{N}$ topdressing in the bean crop in order to avoid the excessive application of $\mathrm{N}$.

\section{Acknowledgments}

To Fundação de Amparo à Pesquisa do Estado de São Paulo (Fapesp), for granting scholarships to the first and third authors (processes No. 2011/08874-4 and 2011/19594-2, respectively), as well as for financial support (process No. 2011/18218-7); to Conselho Nacional de Desenvolvimento Científico e Tecnológico (CNPq), for providing a productivity scholarship in research to the second author; and to Instituto Federal Goiano, for scholarship granted to the first author and for financial support (process No. 23731.000064/201716).

\section{References}

AMBROSANO, E.J.; TANAKA, R.T.; MASCARENHAS, H.A.A.; RAIJ, B. van; QUAGGIO, J.A.; CANTARELLA, H. Leguminosas e oleaginosas. In: RAIJ, B. van; CANTARELLA, H.; QUAGGIO, J.A.; FURLANI, A.M.C. (Ed.). Recomendações de adubação e calagem para o Estado de São Paulo. 2.ed. Campinas: Instituto Agronômico: Fundação IAC, 1997. p.189203. (IAC. Boletim técnico, 100).

BARBOSA FILHO, M.P.; COBUCCI, T.; FAGERIA, N.K.; MENDES, P.N. Determinação da necessidade de adubação nitrogenada de cobertura no feijoeiro irrigado com auxílio do clorofilômetro portátil. Ciência Rural, v.38, p.1843-1848, 2008. DOI: 10.1590/S0103-84782008000700007.

BARBOSA FILHO, M.P.; COBUCCI, T.; FAGERIA, N.K.; MENDES, P.N. Época de aplicação de nitrogênio no feijoeiro irrigado monitorada com auxílio de sensor portátil. Ciência e Agrotecnologia, v.33, p.425-431, 2009. DOI: 10.1590/S141370542009000200010.

CARVALHO, M.A.C.; ARF, O.; SÁ, M.E.; BUZETTI, S.; SANTOS, N.C.B.; BASSAN, D.A.Z. Produtividade e qualidade de sementes de feijoeiro (Phaseolus vulgaris L.) sob influência de parcelamentos e fontes de nitrogênio. Revista Brasileira de Ciência do Solo, v.25, p.617-624, 2001. DOI: 10.1590/S010006832001000300010.

CHAPMAN, S.C.; BARRETO, H.J. Using a chlorophyll meter to estimate specific leaf nitrogen of tropical maize during vegetative growth. Agronomy Journal, v.89, p.557-562, 1997. DOI: 10.2134/ agronj1997.00021962008900040004x.

CRUSCIOL, C.A.C.; SORATTO, R.P.; SILVA, L.M. da; LEMOS, L.B. Fontes e doses de nitrogênio para o feijoeiro em sucessão 
a gramíneas no sistema plantio direto. Revista Brasileira de Ciência do Solo, v.31, p.1545-1552, 2007. DOI: 10.1590/S010006832007000600031 .

DWYER, L.M.; ANDERSON, A.M.; MA, B.L.; STEWART, D.W.; TOLLENAAR, M.; GREGORICH, E. Quantifying the nonlinearity in chlorophyll meter response to corn leaf nitrogen concentration. Canadian Journal of Plant Science, v.75, p.179182, 1995. DOI: 10.4141/cjps95-030.

HUSSAIN, F.; BRONSON, K.F.; YADVINDER-SINGH; BIJAYSINGH; PENG, S. Use of chlorophyll meter sufficiency indices for nitrogen management of irrigated rice in Asia. Agronomy Journal, v.92, p.875-879, 2000.

KLUTHCOUSKI, J.; AIDAR, H.; THUNG, M.; OLIVEIRA, F.R. de A.; COBUCCI, T. Manejo antecipado do nitrogênio nas principais culturas anuais. Santo Antônio de Goiás: Embrapa Arroz e Feijão, 2006. 63p. (Embrapa Arroz e Feijão. Documentos, 188).

LI, L.; QIN, Y.; LIU, Y.; HU, Y.; FAN, M. Leaf positions of potato suitable for determination of Nitrogen content with a SPAD meter. Plant Production Science, v.15, p.317-322, 2012. DOI: 10.1626/ pps.15.317.

MAIA, S.C.M.; SORATTO, R.P.; BIAZOTTO, F. de O.; ALMEIDA, A.Q. de. Estimativa da necessidade de nitrogênio em cobertura no feijoeiro IAC Alvorada com clorofilômetro portátil. Semina: Ciências Agrárias, v.34, p.2229-2238, 2013. DOI: 10.5433/1679-0359.2013v34n5p2229.

MAIA, S.C.M.; SORATTO, R.P.; NASTARO, B.; FREITAS, L.B. de. The nitrogen sufficiency index underlying estimates of nitrogen fertilization requirements of common bean. Revista Brasileira de Ciência do Solo, v.36, p.183-191, 2012. DOI: 10.1590/S0100-06832012000100019.

MALAVOLTA, E.; VITTI, G.C.; OLIVEIRA, S.A. de. Avaliação do estado nutricional de plantas: princípios e aplicações. 2.ed. Piracicaba: Associação Brasileira para Pesquisa da Potassa e do Fosfato, 1997. 319p.

PEREZ, A.A.G.; SORATTO, R.P.; MANZATTO, N.P.; SOUZA, E. de F.C. de. Extração e exportação de nutrientes pelo feijoeiro adubado com nitrogênio, em diferentes tempos de implantação do sistema plantio direto. Revista Brasileira de Ciência do Solo, v.37, p.1276-1287, 2013. DOI: 10.1590/S0100-06832013000500017.

RAPASSI, R.M.A.; SÁ, M.E. de; TARSITANO, M.A.A.; CARVALHO, M.A.C. de; PROENÇA, É.R.; NEVES, C.M.T. de C.; COLOMBO, E.C.M. Análise econômica comparativa após um ano de cultivo do feijoeiro irrigado, no inverno, em sistemas de plantio convencional e direto, com diferentes fontes e doses de nitrogênio. Bragantia, v.62, p.397-404, 2003. DOI: 10.1590/ S0006-87052003000300006.
ROSOLEM, C.A.; MELLIS, V. van. Monitoring nitrogen nutrition in cotton. Revista Brasileira de Ciência do Solo, v.34, p.16011607, 2010. DOI: 10.1590/S0100-06832010000500013.

SANTOS, A.B. dos; FAGERIA, N.K. Manejo do nitrogênio para eficiência de uso por cultivares de feijoeiro em várzea tropical. Pesquisa Agropecuária Brasileira, v.42, p.1237-1248, 2007. DOI: $10.1590 / \mathrm{s} 0100-204 \times 2007000900004$.

SANTOS, H.G. dos; JACOMINE, P.K.T.; ANJOS, L.H.C. dos; OLIVEIRA, V.A. de; OLIVEIRA, J.B. de; COELHO, M.R.; LUMBRERAS, J.F.; CUNHA, T.J.F. (Ed.). Sistema brasileiro de classificação de solos. 2.ed. Rio de Janeiro: Embrapa Solos, 2006. 306p.

SILVEIRA, P.M. da; BRAZ, A.J.B.P.; DIDONET, A.D. Uso do clorofilômetro como indicador da necessidade de adubação nitrogenada em cobertura no feijoeiro. Pesquisa Agropecuária Brasileira, v.38, p.1083-1087, 2003. DOI: 10.1590/S0100204X2003000900009.

SORATTO, R.P.; CARVALHO, M.A.C. de; ARF, O. Teor de clorofila e produtividade do feijoeiro em razão da adubação nitrogenada. Pesquisa Agropecuária Brasileira, v.39, p.895-901, 2004. DOI: 10.1590/S0100-204X2004000900009.

SORATTO, R.P.; CRUSCIOL, C.A.C.; SILVA, L.M. da; LEMOS, L.B. Aplicação tardia de nitrogênio no feijoeiro em sistema de plantio direto. Bragantia, v.64, p.211-218, 2005. DOI: 10.1590/ S0006-87052005000200007.

SORATTO, R.P.; FERNANDES, A.M.; PILON, C.; CRUSCIOL, C.A.C.; BORGUI, E. Épocas de aplicação de nitrogênio em feijoeiro cultivado após milho solteiro ou consorciado com braquiária. Pesquisa Agropecuária Brasileira, v.48, p.13511359, 2013a. DOI: 10.1590/S0100-204X2013001000006.

SORATTO, R.P.; FERNANDES, A.M.; SANTOS, L.A. dos; JOB, A.L.G. Nutrient extraction and exportation by common bean cultivars under different fertilization levels: I - macronutrients. Revista Brasileira de Ciência do Solo, v.37, p.1027-1042, 2013b. DOI: $10.1590 / \mathrm{S} 0100-06832013000400020$.

SORATTO, R.P.; PEREZ, A.A.G.; FERNANDES, A.M. Age of no-till system and nitrogen management on common bean nutrition and yield. Agronomy Journal, v.106, p.809-820, 2014. DOI: 10.2134 /agronj13.0439.

TAIZ, L.; ZEIGER, E. Fisiologia vegetal. 5.ed. Porto Alegre: Artmed, 2013. 918p.

ZHOU, Q.; WANG, J. Comparison of upper leaf and lower leaf of rice plants in response to supplemental nitrogen levels. Journal of Plant Nutrition, v.26, p.607-617, 2003. DOI: 10.1081/PLN120017668 .

$\overline{\text { Received on August 21, } 2015 \text { and accepted on October 20, } 2016}$ 